\title{
SELF FULFILLING DEBT CRISIS IN AN OIL EXPORTING ECONOMY
}

\author{
Kamal Romero* \\ Universidad Rey Juan Carlos ${ }^{\dagger}$
}

\begin{abstract}
Venezuela's government presents a debt structure biased toward instruments with short maturities mostly held by international bankers. However, the government has access to windfall revenues associated to oil exports that enhance its creditworthiness. A version of Cole and Kehoe (2000) model of debt crises augmented to incorporate income windfalls in the government sector is presented, and the possibility for a non-default equilibrium evaluated. Default is predicted for the Venezuelan economy without favorable terms of trade shocks. A crisis can be eliminated for a given size of the income windfall though. For those cases where the economy fail to exit the crisis zone, the combination of policies needed to abandon such a region is far more feasible to implement when a big oil rent is present.
\end{abstract}

Keywords: Public Debt, default, multiple equilibria, oil windfall.

JEL code: E60, F34, H30

*I thank Eduardo Giménez, Francisco Lores and Luis A. Puch for helpful comments and suggestions, as well as the participants in seminars and conferences where this work has been presented. I also acknowledges Venezuela's Ministry of Finance for their support during a summer research visit. All remaining errors are mine. The views expressed in this paper are those of the author

${ }^{\dagger}$ Correspondence: Universidad Rey Juan Carlos, Campus de Vicálvaro, edificio departamental, despacho 179, Paseo de los Artilleros s/n. Madrid 28032. Tlf: (34) 914888023. Fax: (34) 914887779. E-mail: karomero@ccee.ucm.es and kamal.romero@urj.es 


\section{Introduction}

Public debt financing in Venezuela has shifted to local market operations (in local currency) over the recent years. The share of internal debt within the total debt increased to $35.6 \%$ by the end of 2004 , from about a $10.0 \%$ recorded in the early nineties.

The absence of a well developed local financial market leads to an internal debt that is characterized by low liquidity, and therefore, shorter maturities than those reported for external debt. ${ }^{1}$ Risk premia and term premia reflect not only the lower liquidity in the local market, but also the real value loss implicit in instruments denominated in local currency. On top of that, the uncertainty associated to macroeconomic and political instability is reflected in both maturities and yields of internal debt. This results in shortened and enlarged maturities in response to expectations of devaluation and inflation.

A shift to shorter maturities combined with a weak or rigid tax code and risk premia induce debt rollover in local markets. International organizations have warned about rollover risk in emerging markets due to the increasing reliance on local debt markets. For example World Bank mentions in 2003:

"By contrast, most debt issues in emerging local markets are concentrated at the short end of the curve (...) Short maturities leave government borrowers open to considerable rollover risk in the early stages of their transition from international to local markets." 2 .

And in 2005 reassert:

"Increased reliance on domestic debt raises rollover risk (because it is generally shorter in maturity than external debt), as well as interest rate risk" ${ }^{3}$.

By the same token the International Monetary Fund states in 2003:

"Liquidity conditions are also important. Even if a government satisfies its present value budget constraint, it may not have sufficient assets and financing available to meet o roll over its maturing liabilities"4.

In a previous work (Our work, citation eliminated) we have pointed out that the Venezuelan economy is exposed to a rollover risk as a result of the situation described. The inability of the government to rollover its debt at a point in time could render a liquidity crisis into a debt crisis.

\footnotetext{
${ }^{1}$ For a deeper analysis on the structure of local debt markets in developing economies see Borenztein, Chamon, Jeanne, Mauro, and Zettelmeyer (2004)

${ }^{2} \mathrm{WB}(2003$, page 55$)$

${ }^{3} \mathrm{WB}(2005$, page 82$)$

${ }^{4} \mathrm{IMF}$ (2003, page 122)
} 


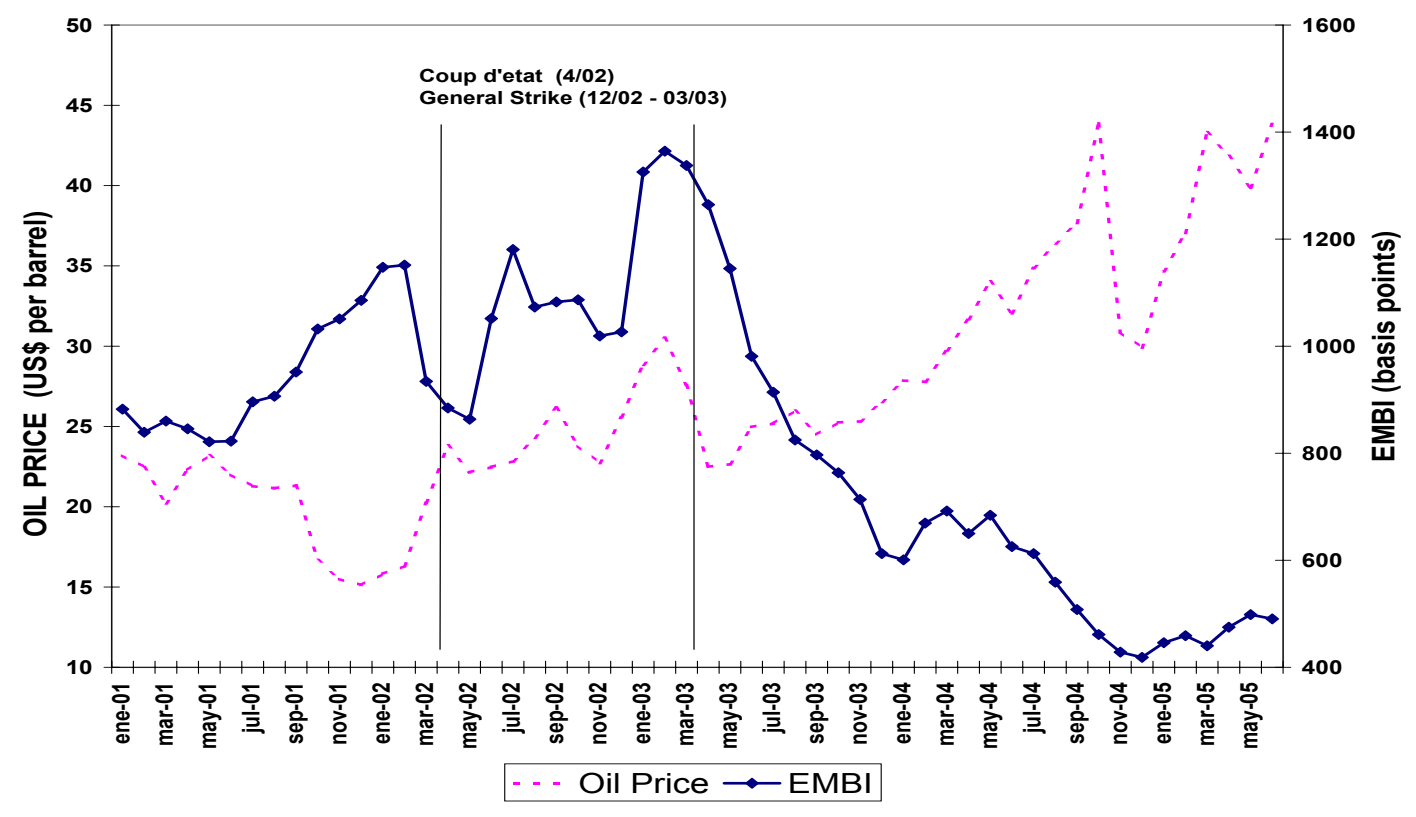

Figure 1: Oil Price and Sovereign Bond Risk

In order to quantify the exposure to rollover risk we build upon Cole and Kehoe (2000) model of debt crises. The model allows to determine if the current level of debt of the Venezuelan economy is inside a region called "crisis zone" where adverse private agent's beliefs can drive the fiscal authority to a public debt default. As Cole and Kehoe (1996) discuss for Mexico, regardless the economy presented sound macroeconomic fundamentals, it was in a crisis zone due to the sharp decrease of debt maturity, that generated a rollover problem as soon as international bankers refused to acquire new debt issues. Here we argue that, taking the 2003 debt to GDP ratio as the initial debt level, Venezuelan public debt was in a crisis zone where a self fulfilling crisis can occur in a stochastic manner given the realization of a sunspot variable. Nevertheless, we observe that the likelihood of occurrence of a debt crisis in Venezuela is low, due to the huge government revenues, as a consequence of the high oil prices experienced during the last four years.

Indeed, the monthly average nominal price of the Venezuelan oil basket during 20002005 exceeded by $79.6 \%$ and $87.6 \%$ the 1995-1999 and 1991-1995 figures, respectively. Additionally, oil accounted for $49.6 \%$ of total Government revenues and $81 \%$ of total goods exports in 2003. In Figure 1 we plot the price of the Venezuelan oil basket and the JP Morgan EMBI index for Venezuela, we can observe how market sentiment about a default expressed in bond spreads is clearly negatively related to oil prices. Only the 
period between April 2002 and April 2003 does not follow such a pattern, due to the April 2002 failed coup d'etat and the general strike that took place between December 2002 and March 2003. The correlation index for the complete sample is -0.7 , excluding the abnormal period mentioned above, correlation increases to -0.9. Therefore, agents observe a notable increase in creditworthiness that counteracted a rollover risk due to short term debt structure.

With these considerations, this paper expands Cole and Kehoe (2000) model to include the oil windfall feature. Specifically, we include an exogenous income in the government budget constraint that acts as a foreign transfer. Then, we carry out experiments using different specifications for the oil windfall, fixing the transfer such that it reproduces the size of the Venezuelan Government's oil revenue. We determine the size of the crisis zone and the combination of policies the government can pursue in order to abandon such a zone and the feasibility of these policies. We find that the limits of the crisis zone depends on the size of the windfall. Also, we determine that the combination of policies needed to abandon the zone are far more feasible to implement than those implied by an environment without oil income.

The paper is organized as follows. In the next section, we briefly describe the public debt structure in Venezuela. In section 3, we describe Cole and Kehoe (1996) model augmented to incorporate the oil windfall, whereas in section 4 we proceed to make a numerical exercise for an economy like the one described in the third section, we parameterize the model to reproduce some important features of the Venezuelan economy. The last section concludes.

\section{Public Debt Performance in Venezuela.}

The re-composition of total debt in favor of the domestic market leads to shorter-term debt instruments, lower liquidity, and a higher exposure to losses in the real value of debt, when both inflation and devaluation episodes are discounted. This, combined with clear higher-nominal-yield debt instruments has implied the following:

- Higher fiscal vulnerability, since new debt has a more volatile yield, and -in addition-, a higher frequency of debt issues in order to ensure the short-term debt rollover.

- Higher liquidity requirements in the internal market that become necessary to absorb new debt issues in local currency. 
From the situation described above, it becomes essential for the government to place debt in a more frequent way, which requires a stable demand for domestic debt. In addition, this demand depends on the financial health in the fiscal accounts, which worsens as the government issues a higher amount of internal debt.

This situation involves a circularity in which the real solvency of the government depends more on the desire of bondholders to accept new papers, without disregarding the expectations about the ability of the government to meet its liabilities.

This will be the key of the results of the model that we develop in the below sections. In this way, we proceed to describe the debt recomposition mentioned above.

\section{Public Debt Composition}

The weight of public debt in terms of GDP has been decreasing over the past years, from $48.9 \%$ in 1996 , to $39 \%$ in 2004 , which is fully explained by a fall in external liabilities from $41.3 \%$ to $25.1 \%$. In contrast, internal debt increased to $13.9 \%$, from $7.6 \%$ in the 1996-2004 period. This increase in the ratio of domestic debt to GDP has led to an increase in the local liabilities on total debt stock, although it has not reached the most important component of it. In table 1 we see how internal debt more than doubled its weight of total debt, from $15.5 \%$ to $35.6 \%$ in 2004 .

This recomposition has also been reflected in both the debt service structure and the use of fiscal revenues in Venezuela. In fact, the debt-service-to-GDP ratio has expanded from $6.7 \%$ to $8.6 \%$ over the $1996-2003$ period, as a result of the increase in domestic debt service from $2.3 \%$ to $4.8 \%$, and in detriment of the external debt service which reduce to $3.8 \%$, from $4.4 \%$ in 1996 .

This situation implies that a higher amount of fiscal revenue is used to serve internal debt. We see that for the beginning of the period, both internal and external debt service were equivalent to $23.98 \%$ and $23.3 \%$ of total fiscal revenues, respectively. For 2002, and despite the stability of external debt service at around $22.53 \%$, public debt denominated in local currency suffered an important jump, reaching $60.2 \%$, which increased total debt service to $82.73 \%$, from $47.29 \%$ recorded in $1996 . .^{5}$

The larger size in the internal debt service could be explained not only by the increase in the stock itself, but also by the lower maturities in which those transactions were effectively made. Actually, by a simple inspection of figure 2, we see how before the domestic debt repurchase operations made in March 2004, 89.0\% of internal debt

\footnotetext{
${ }^{5}$ Source: OAEF (2003).
} 


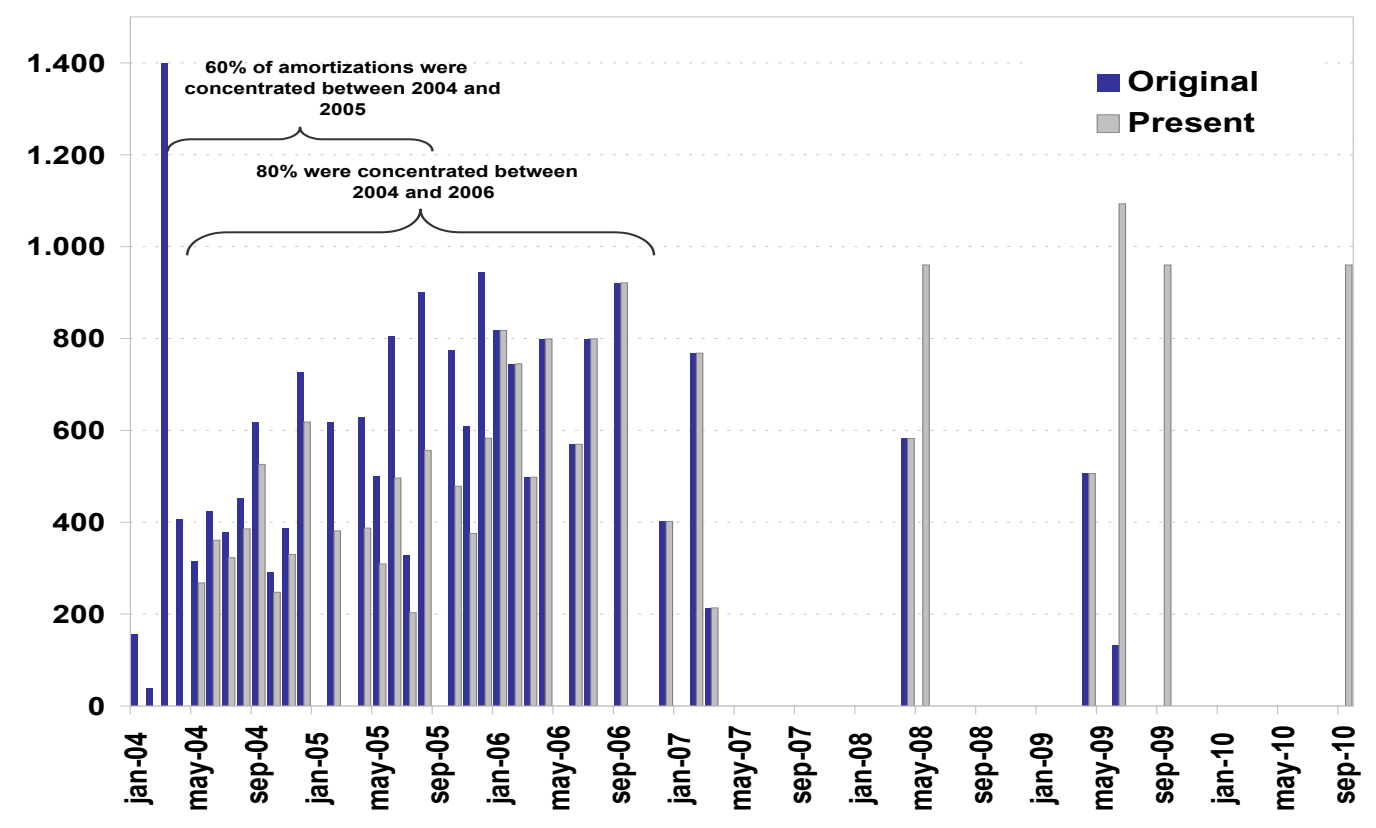

Figure 2: Local Currency Public Debt Amortization Schedule

amortizations was concentrated between 2004-2006.

In sum, we could say that despite the reduction in external public debt, the increase in the stock of domestic debt was characterized by lower average maturity and a rise in the total debt service. One of the consequences of such a scenario is the need to place a greater quantity of debt more frequently.

\section{A Debt Crisis Model}

We propose a stochastic general equilibrium model of a small open economy ala Cole and Kehoe (2000), augmented to incorporate an oil windfall. We treat the oil windfall as a pure rent associated with a foreign transfer, given that in main oil exporting countries most of the oil output is sold in international markets.

An interesting feature of this extension is that it does not alter any of the results obtained in Cole and Kehoe (2000), in terms of the characterization of equilibria.

\subsection{Environment}

There is a single perishable good which can be either consumed or saved as capital in each period $t=0,1, \ldots$ There are three types of agents: a government that issues debt, collects taxes and receives a foreign transfer in order to finance a sequence of 
Table 1: Venezuelan Public Debt

\begin{tabular}{|c|c|c|c|c|c|}
\hline & $\begin{array}{l}\text { Total Debt } \\
\text { GDP (\%) }\end{array}$ & $\begin{array}{c}\text { cternal Debt } \\
G D P(\%)\end{array}$ & $\begin{array}{c}\text { ternal Debt } \\
G D P(\%)\end{array}$ & $\begin{array}{l}\text { Internal Debt/ } \\
\text { Total Debt (\%) }\end{array}$ & $\begin{array}{l}\text { External Debt } \\
\text { Total Debt (\%) }\end{array}$ \\
\hline 1996 & 48,9 & 41,3 & 7,6 & 15,5 & 84,5 \\
\hline 1997 & 32,9 & 27,9 & 5 & 15,2 & 84,8 \\
\hline 1998 & 29,6 & 25,2 & 4,4 & 14,9 & 85,1 \\
\hline 1999 & 29,3 & 23,6 & 5,7 & 19,4 & 80,6 \\
\hline 2000 & 27,2 & 18,7 & 8,5 & 31,3 & 68,7 \\
\hline 2001 & 30,4 & 18,9 & 11,5 & 37,9 & 62,1 \\
\hline 2002 & 42,7 & 28,5 & 14,2 & 33,3 & 66,7 \\
\hline 2003 & 45,9 & 28,9 & 17 & 36,9 & 63,1 \\
\hline 2004 & 39 & 25,1 & 13,9 & 35,6 & 64,4 \\
\hline
\end{tabular}

Source: Venezuela Ministry of Finance

public expenditure, a financial sector or bankers that purchase government bonds and finally consumers-producers who have access to a technology that transforms productive capital and in an implicit manner labor (we assume leisure is not an argument of the utility function and therefore labor is offered inelastically) in the perishable good, also they do not have access to debt markets, so their savings only take the form of capital accumulation. We describe each type of agents in turn:

\section{Consumers}

There is a continuum of measure one of identical, infinitely lived consumers who consume, invest and pay taxes. Their ordering of the perishable good (private consumption) and government expenditure (public consumption) is represented by a continuous differentiable, strictly concave and monotonically increasing utility function of the form:

$$
E \sum_{t=0}^{\infty} \beta^{t}\left(c_{t}+v\left(g_{t}\right)\right)
$$

where $c_{t}$ y $g_{t}$ represent private and public consumption respectively. We assume $\beta \in$ $(0,1)$. Consumption choices are restricted to belong to the feasible set given by the budget constraint:

$$
c_{t}+k_{t+1}-k_{t} \leq(1-\theta)\left(a_{t} f\left(k_{t}\right)-\delta k_{t}\right)
$$

$a_{t}$ is a multiplicative productivity factor that depends on whether or not the government has ever defaulted, if the fiscal authority pays its debt $a_{t}=1$, if it defaults $a_{t}=$ 
$\alpha<1$ period $t$ thereafter $^{6} ; \delta \in(0,1)$ is the depreciation factor; $\theta \in(0,1)$ is the constant proportional tax on income ${ }^{7}$; and $f$ is a continuously differentiable, concave and monotonically increasing production function that satisfies $f(0)=0, f^{\prime}(0)=\infty$, and $f^{\prime}(\infty)=0$ or the so-called Inada conditions. Each consumer is endowed with $k_{0}$ units of capital in period 0 .

\section{Bankers}

The only function of the financial sector in the model is to purchase government debt, therefore it possesses a very stylized utility function and a government decision to default is reflected in their budget constraint. Bankers must infer the government's decision to honor its debt and incorporate these expectations in the price they are willing to pay for new debt issues.

The assumption that only bankers purchase public debt reflects a main feature of the Venezuelan debt market, where the financial sector is by far the greatest (actually the only) participant in primary auctions. The fraction of public debt held by the banking sector is estimated to be of $88 \%^{8}$.

There is a continuum with measure one of identical, infinitely lived bankers. These bankers are risk neutral ${ }^{9}$ and their preferences over the endowment of the consumption good they receive $(\bar{x})$ are represented by the following utility function:

$$
E \sum_{t=0}^{\infty} \beta^{t} x_{t}
$$

Bankers maximize 3.1 subject to the budget constraint:

$$
x_{t}+q_{t} b_{t+1} \leq \bar{x}+z_{t} b_{t}
$$

where $q_{t}$ is the price paid for a one-period government bond that pays $b_{t+1}$ in $t+1$. $z_{t} \in(0,1)$ summarizes the government default decision, if $z=0$ it defaults, if $z=1$ it pays its debt. Banks hold $b_{0}$ in $t=0$

\footnotetext{
${ }^{6}$ For a couple of reasonable justifications for this assumption see Cole and Kehoe (2000, section 2)

${ }^{7}$ This assumption records the tax policy rigidity mentioned in previous sections

${ }^{8}$ Official figures about the distribution of public debt among institutional sectors are not available. We estimated this number based on banks disaggregated balance sheets.

${ }^{9}$ This assumption captures the idea that the domestic economy is small compared to world financial markets. See Cole and Kehoe (1996)
} 


\section{Government}

There exists a government that in every period decides its new level of borrowing $B_{t+1}$; whether or not to default on the previous period debt $z_{t}$; and the level of public expenditure $g_{t}$. Initial level of debt is $B_{0}=b_{0}$.

Besides taxes and debt, the government receives an exogenous income as a transfer. We will assume different specifications (exogenous, endogenous, stochastic) for this transfer. We name such income $\lambda_{t}$, and it represents the oil windfall feature.

The government is benevolent in the sense that its objective is to maximize the consumers-producers utility function subject to:

$$
g_{t}+z_{t} B_{t} \leq \theta\left(a_{t} f\left(k_{t}\right)-\delta k_{t}\right)+q_{t} B_{t+1}+\lambda_{t}
$$

As Cole and Kehoe (1996) mentions there is no need to impose a borrowing constraint that rules out Ponzi schemes, because if the government tries to issue too much new debt $B_{t+1}$ its price $q_{t}$ falls to zero.

In each period $t$ there is an exogenous sunspot variable $\zeta_{t}$ whose value is realized. We assume such a variable is i.i.d in the interval $[0,1]$. This variable represents expectations not linked to the model fundamentals represented by preferences, technology and endowments. In a model of this type it is possible to construct multiple equilibria, where at least one of such equilibria depends on beliefs not linked to the model structure; it will be possible to reach a bad equilibrium just because agents think events are going to be bad, as long as such beliefs are confirmed in equilibrium. ${ }^{10}$

This will be the sunspot variable role in this model. For a given range of debt level where the government can honor its debt obligations whenever it can rollover the old debt, if the variable $\zeta_{t}$ is below some crucial level then bankers are not willing to purchase the new debt, the price is $q_{t}=0$ and the government defaults, validating agents expectations and generating a self-fulfilling debt crisis. If on the contrary, variable $\zeta_{t}$ is above the crucial level, bankers buy the new issues at a positive price and the fiscal authority can pay the old debt, resulting in a good equilibrium.

It is possible to observe in this setting the circularity that multiple equilibria models usually present, the cost of no default increases as bankers ascribe a greater risk premium over the new bond issue price ${ }^{11}$, which in turn depends on their expectations on

\footnotetext{
${ }^{10}$ For an introductory treatment of this topic see Farmer (1993, Chap. 10)

${ }^{11}$ Bankers demand a greater yield that compensates for the increased probability of default, resulting in a bond price reduction. When the default probability is 1 bond price is $q_{t}=0$, we will return to this point further when we analyze agent's strategies contingent to default expectations
} 
government willingness to pay.

We observe that equilibria will depend only on expectations for a given range of debt level, that in which government creditworthiness depends on its capacity to sell new debt issues. In a simple way we can describe this range as one above a level of debt $\bar{b}$ below which the government will always honor its financial liabilities, regardless of whether it sells new debt or not; and below another level $\bar{B}$ from which time onwards it will default even if it sells new debt.

\section{Timing of Actions}

The timing of actions within each period is the following:

- Sunspot variable $\zeta_{t}$ is realized, the aggregate state is $s_{t}=\left(B_{t}, K_{t}, a_{t-1}, \zeta_{t}, \lambda_{t}\right)$

- The government, taking the price schedule $q_{t}=q\left(s_{t}, B_{t+1}\right)$ as given, chooses $B_{t+1}$

- The bankers taking $q_{t}$ choose whether to purchase $B_{t+1}$ or not

- The government chooses whether or not to default $z_{t}$, and the level of public expenditure $g_{t}$

- The consumers-producers taking $a_{t}$ as given, chooses $c_{t}$ and $k_{t+1}$. In equilibrium $k_{t+1}=K_{t+1}$

The timing of events is a crucial aspect of this model, since it gives the government an important strategic role issuing new debt before withdrawing the old debt, while having a maturity of one period on the debt. On the other hand it relegates the consumers to a passive role, being the last agent to take their decisions.

The non-existence of a commitment technology, the possibility of this and the timing of events offer the government to default optimally, the realization of the sunspot variable previous to the debt offering, the oil windfall and especially the need to rollover debt into new one, comprise the key elements that drive the results of the paper.

\subsection{Equilibrium}

As Cole and Kehoe (2000), we define a recursive equilibrium in which there is no commitment and the agent's choose their actions sequentially. For this reason we write the agent's problems in a recursive form ${ }^{12}$. The state of an individual agent consists of the

\footnotetext{
${ }^{12} \mathrm{We}$ adopt the standard notation that eliminates the time subscripts and indicate next period variables with a prime over the variable
} 
aggregate state, any individual state variable, and any relevant variable that has already been chosen within the period that affects their maximization problem or next period state.

We start with those who take their decisions last, the consumers-producers. When they are ready to choose $c$ and $k^{\prime}$ they know the aggregate state $s=\left(B, K, a_{-1}, \zeta, \lambda\right)$; the new government debt $B^{\prime}$; the price the bankers are willing to pay for this debt $q$; the government expenditure $g$ and default decision $z$. Since the consumers-producers do not hold debt, their decisions only depend on $q$ through its effect on $g$ y $z$ via the government constraint, so we can obviate this variable and define the state of the individual consumer as $\left(k, s, B^{\prime}, g, z\right)$. The representative consumer's value function is given by the following functional equation:

$$
\begin{aligned}
V_{c}\left(k, s, B^{\prime}, g, z\right) & =\max _{c, k^{\prime}}\left[c+v(g)+\beta E V_{c}\left(k^{\prime}, s^{\prime}, B^{\prime}\left(s^{\prime}\right), g^{\prime}, z^{\prime}\right)\right] \\
& \text { subject to } \\
& c+k^{\prime}-k \leq(1-\theta)(a(s, z) f(k)-\delta k) \\
& c, k^{\prime} \geq 0 \\
& s^{\prime}=\left(B^{\prime}, K^{\prime}\left(s, B^{\prime}, g, z\right), a(s, z), \zeta^{\prime}, \lambda^{\prime}\right) \\
& g^{\prime}=g\left(s^{\prime}, B^{\prime}\left(s^{\prime}\right), q\left(s, B^{\prime}\left(s^{\prime}\right)\right)\right) \\
& z^{\prime}=z\left(s^{\prime}, B^{\prime}\left(s^{\prime}\right), q\left(s, B^{\prime}\left(s^{\prime}\right)\right)\right)
\end{aligned}
$$

Where $B^{\prime}\left(s^{\prime}\right), g\left(s^{\prime}, B^{\prime}, q\right)$ y $z\left(s^{\prime}, B^{\prime}, q\right)$ are the government policy functions, $q\left(s, B^{\prime}\right)$ is the price function, all derived as the results of the public and financial sectors optimization programs we describe later. $K^{\prime}\left(s, B^{\prime}, g, z\right)$ is the function that describes the evolution of the aggregate capital stock, which is in equilibrium given the assumption of competitive and identical consumers $K^{\prime}=k^{\prime 13}$. As we mentioned before $a(s, z)$ summarize the government default decision and take values $a(s, z)=1$ if $a_{-1}=1$ and $z=1$, and $a(s, z)=\alpha<1$ otherwise.

When an individual banker solves his program he knows his holdings of debt $b$, the aggregate state $s$ and the new issue of government debt $B^{\prime}$. We therefore define his

\footnotetext{
${ }^{13}$ See Cole and Kehoe (1996)
} 
individual state as $\left(s, b, B^{\prime}\right)$ and individual value function by the functional equation:

$$
\begin{aligned}
V_{b}\left(s, b, B^{\prime}\right) & =\max _{x, b^{\prime}}\left[x+\beta E V_{b}\left(s^{\prime}, b^{\prime}, B^{\prime}\left(s^{\prime}\right)\right)\right] \\
& \text { subject to } \\
& x+q\left(s, B^{\prime}\right) b^{\prime} \leq \bar{x}+z\left(s, B^{\prime}, q\left(s, B^{\prime}\right)\right) b \\
& x \geq 0, \quad b^{\prime} \geq-A \\
& s^{\prime}=\left(B^{\prime}, K^{\prime}\left(s, B^{\prime}, g, z\right), a(s, z), \zeta^{\prime}, \lambda^{\prime}\right) \\
& g^{\prime}=g\left(s^{\prime}, B^{\prime}\left(s^{\prime}\right), q\left(s, B^{\prime}\right)\right) \\
& z^{\prime}=z\left(s^{\prime}, B^{\prime}\left(s^{\prime}\right), q\left(s, B^{\prime}\right)\right)
\end{aligned}
$$

Given that bankers are assumed to be risk neutral and to behave competitively, their behavior is relatively passive: If $\bar{x}$ are large enough they purchase any amount of debt offered by the government, as long as the bond price satisfies the standard Euler equation $q\left(s, B^{\prime}\right)=\beta E z\left(s^{\prime}, B^{\prime}\left(s^{\prime}\right), q\left(s, B^{\prime}\left(s^{\prime}\right)\right)\right)$, or in other words the yield is equal to $1 / \beta^{14}$

Unlike the rest of the agents, the government makes decisions at two points in time. In one of such moves he knows the banker's decisions and the effect of his actions on consumers, therefore he is the only agent that acts strategically.

At the beginning of events the government chooses $B^{\prime}$ given $s$, additionally it knows how the price of the issue depends on the previous variables $q\left(s, B^{\prime}\right)$. The government also knows what its optimizing choices $z\left(s, B^{\prime}, q\left(s, B^{\prime}\right)\right)$ and $g\left(s, B^{\prime}, q\left(s, B^{\prime}\right)\right)$ will be later, and is aware that its decisions affect the technology parameter $a$ and therefore consumption $c$ and investment $k^{\prime}$.

The government value function is given by the following functional equation:

$$
\begin{aligned}
& V_{g}(s)=\max _{B^{\prime}}\left[c\left(K, s, B^{\prime}, g^{\prime}, z^{\prime}\right)+v(g)+\beta E V_{g}(s)\right] \\
& \text { subject to } \\
& s^{\prime}=\left(B^{\prime}, K^{\prime}\left(s, B^{\prime}, g, z\right), a(s, z), \zeta^{\prime}, \lambda^{\prime}\right) \\
& g^{\prime}=g\left(s^{\prime}, B^{\prime}\left(s^{\prime}\right), q\left(s, B^{\prime}\right)\right) \\
& z^{\prime}=z\left(s^{\prime}, B^{\prime}\left(s^{\prime}\right), q\left(s, B^{\prime}\right)\right)
\end{aligned}
$$

In its second move the government decides whether to default or not $(z)$, which in turn determines the productivity parameter $a$ and therefore the level of public consumption $g$. Given the government's value function $V_{g}(s)$, we can define the policy functions

\footnotetext{
${ }^{14}$ As Cole and Kehoe (2000) mentions we can interpret this Euler equation as an arbitrage condition of a small open economy and drop the explicit treatment of bankers
} 
$z\left(s, B^{\prime}, q\left(s, B^{\prime}\right)\right)$ and $g\left(s, B^{\prime}, q\left(s, B^{\prime}\right)\right)$ as the solution to the problem:

$$
\begin{aligned}
& \max _{g, z}\left[c\left(K, s, B^{\prime}, g^{\prime}, z^{\prime}\right)+v(g)+\beta E V_{g}(s)\right] \\
& \text { subject to } \\
& g+z B \leq \theta(a(s, z) f(K)-\delta k)+q B^{\prime}+\lambda \\
& z=0 \quad \text { o } \quad z=1 \\
& g \geq 0 \\
& s^{\prime}=\left(B^{\prime}, K^{\prime}\left(s, B^{\prime}, g, z\right), a(s, z), \zeta^{\prime}, \lambda^{\prime}\right)
\end{aligned}
$$

Given the objects described above and the timing of events, we can define the recursive equilibrium for this economy.

Definition 3.1. An equilibrium is a list of value functions, $V_{c}$ for the consumerproducer, $V_{b}$ for the banker and $V_{g}$ for the government; of policy functions $c$ and $k^{\prime}$ for the consumer-producer, $b^{\prime}$ for the bankers and $B^{\prime}, g$ and $z$ for the government; a price function $q$ and an equation of motion for aggregate capital $K^{\prime}$, such that:

- Given $B^{\prime}, g$ and $z, V_{c}$ is the value function that maximizes 3.2 and $c$ and $k^{\prime}$ are the optimal decisions

- Given $B^{\prime}, g$ and $z, V_{b}$ is the value function that maximizes 3.3 and the value of $B^{\prime}$ chosen by the government solves the problem when $b=B$

- Given $q, c, g$ and $z, V_{g}$ is the value function that maximizes 3.4 and $B^{\prime}$ the optimal decision. Furthermore, given $c, K^{\prime}, V_{g}$ and $B^{\prime}, g$ and $z$ maximize the consumer's utility subject to the government budget constraint.

- $q\left(s, B^{\prime}\right)=\beta E z\left(s^{\prime}, B^{\prime}\left(s^{\prime}\right), q\left(s, B^{\prime}\left(s^{\prime}\right)\right)\right)$ where $s^{\prime}=\left(B^{\prime}, K^{\prime}\left[s, B^{\prime}, g\left(s, B^{\prime}, q\left(s, B^{\prime}\right)\right), z\left(s, B^{\prime}, q\left(s, B^{\prime}\right)\right)\right], a\left(s, z\left(s, B^{\prime}, q\left(s, B^{\prime}\right)\right)\right), \zeta^{\prime}, \lambda^{\prime}\right)$

- $K^{\prime}\left(s, B^{\prime}, g, z\right)=k^{\prime}\left(K, s, B^{\prime}, g, z\right)$

\section{Defining the Crisis Zone}

Below we summarize in an intuitive manner the principal ideas involved in the determination of the crisis zone. We derive the decision rules for consumers and bankers for a given probability of default, the law of motion for aggregate capital and the bond price 
function, all of which will be used to compute the government value function and its default rule $z^{15}$.

\section{Private Sector Decision Rules}

In the construction of a recursive equilibrium, the first step is to characterize the behavior of the bankers and consumers.

\section{Bankers}

We have already mentioned that, given the assumptions of risk neutrality and competitiveness, banker's behavior was relatively passive, acquiring any amount of bonds offered as long as the bond price holds:

$$
q\left(s, B^{\prime}\right)=\beta E z\left(s^{\prime}, B^{\prime}\left(s^{\prime}\right), q\left(s, B^{\prime}\left(s^{\prime}\right)\right)\right)
$$

Where $z$ is the main variable that bankers infer and determines the new debt pricing.

Given the definition of $\pi$ we can rewrite 3.5 as:

$$
q\left(s, B^{\prime}\right)=\beta(1-\pi)
$$

\section{Consumers}

Given their position in the timing of events the consumers-producers only form expectations about the possible value of the technology parameter $\alpha$, which summarizes the government default decision. Fixing the initial value of capital $k_{t}$ and the possible values of capital stock in $t+2, k_{t+2}^{n}$ and $k_{t+2}^{d}$, where the supraindex $d$ and $n$ denote default and no-default respectively, it is possible to derive households decision rules as the result of the following variational problem:

$$
\begin{aligned}
& \max \quad c_{t}+\beta(1-\pi) c_{t+1}^{n}+\beta \pi c_{t+1}^{d} \\
& \text { subject to } \\
& c_{t}+k_{t+1}-k_{t} \leq(1-\theta)\left(f\left(k_{t}\right)-\delta f\left(k_{t}\right)\right) \\
& c_{t+1}^{n}+k_{t+2}^{n}-k_{t+1} \leq(1-\theta)\left[f\left(k_{t+1}\right)-\delta f\left(k_{t+1}\right)\right] \\
& c_{t+1}^{d}+k_{t+2}^{d}-k_{t+1} \leq(1-\theta)\left[\alpha f\left(k_{t+1}\right)-\delta f\left(k_{t+1}\right)\right] \\
& c_{t}, c_{t+1}^{n}, c_{t+1}^{d}, k_{t+1} \geq 0
\end{aligned}
$$

\footnotetext{
${ }^{15}$ This exposition follows closely the development described in Cole and Kehoe (2000, section 4)
} 
The first order condition of this optimization problem is the standard Euler equation for capital in expected value form:

$$
\frac{1}{\beta}=(1-\theta)\left[(1-\pi+\pi \alpha) f^{\prime}\left(k^{\pi}\right)-\delta\right]
$$

Substituting 3.6 in the budget constraint we obtain the private consumption rule

$$
c^{\pi}=(1-\theta)(f(k)-\delta k)-k^{\pi}+k
$$

By setting $\pi$ equal to zero and one we obtain the consumption rule for the cases in which default has occurred or not.

Given the strict concavity of $f$ it follows that $k^{n}>k^{\pi}>k^{d}$

On the basis of the bankers and consumer's decision rules derived above, and taking as given $\bar{b}(K)$ and $\bar{B}(K, \pi)$ functions, we derive the law of motion for the aggregate capital as:

$$
K^{\prime}\left(B^{\prime}\right)= \begin{cases}k^{n} & \text { if } B^{\prime} \leq \bar{b}\left(k^{n}\right) \quad \text { and } a=1 \\ k^{\pi} & \text { if } \bar{b}\left(K^{n}\right)<B^{\prime} \leq \bar{B}\left(K^{\pi}, \pi\right) \quad \text { and } a=1 \\ k^{d} & \text { otherwise }\end{cases}
$$

in a similar manner we determine the bond price function

$$
q\left(B^{\prime}\right)= \begin{cases}\beta & \text { if } B^{\prime} \leq \bar{b}\left(k^{n}\right) \quad \text { and } z\left(s, B^{\prime}, \hat{\beta}\right)=1 \\ \hat{\beta} & \text { if } \bar{b}\left(K^{n}\right)<B^{\prime} \leq \bar{B}\left(K^{\pi}, \pi\right) \text { and } z\left(s, B^{\prime}, \hat{\beta}\right)=1 \\ 0 & \text { otherwise, }\end{cases}
$$

where $\hat{\beta}=\beta(1-\pi)$

Given these objects, the last step in the construction of a recursive equilibrium is to define the crisis zone.

Let $V_{g}^{n}\left(s, B^{\prime}, q\right)$ and $V_{g}^{d}\left(s, B^{\prime}, q\right)$ denote the payoff of government for not defaulting and defaulting, respectively in state $s=(B, k, 1, ., \lambda)$ after it sold new debt $B^{\prime}$ at price $q$. The government is willing to pay its debt only if the following inequality holds

$$
V_{g}^{n}\left(s, B^{\prime}, q\right) \geq V_{g}^{d}\left(s, B^{\prime}, q\right)
$$

Cole and Kehoe (2000) names the expression 3.7 the participation constraint, in the classic sense that this constraint must hold to ensure that the government honors the 
terms of the debt contract. This expression along with $q=\beta(1-\pi)$, will help us to determine $\bar{B}\left(K^{\pi}, \pi\right)$.

We can also define what condition needs to hold for a crisis to be possible. The government does not weakly prefer to repay its debt even if no lending is possible, that is to say, the following inequality must hold:

$$
V_{g}^{d}(s, 0,0) \geq V_{g}^{n}(s, 0,0)
$$

From this no-lending condition we determine $\bar{b}(K)$ as the upper bound debt at which the government weakly prefers to repay although it cannot sell new debt at a positive price.

In equilibrium, given the probability of default $\pi$ if the level of debt is below $\bar{b}(K)$, bankers predict that, given the low level of debt, the government will pay the outstanding debt whether it places new issues or not. In this case bankers acquire the new issue at a positive price for any value of $\pi$. The opposite occurs if $B>\bar{B}(K)$, the level of debt is so high that the government will always prefer to default whether or not it manages to place new debt, knowing this, for any value of $\pi$ bankers will not pay a positive price for any amount of debt offered.

In the case where $\bar{b}(K)<B \leq \bar{B}(K, \pi)$, if $\zeta \leq \pi$ bankers predict that the fiscal authority will not pay the old debt and therefore fix $q=0$, and thus provoke a crisis. If however $\zeta>\pi$, then bankers predict their debt will be honored, the government can execute the rollover and debt is paid as expected.

Our aim is to analyze if our augmented model can exit the Venezuelan economy from a crisis zone, that is, if the lower limit of such zone increases up to a point that the Venezuelan internal debt/GDP ratio is below $\bar{b}(K)$. Using 3.8, bankers and consumers decision rules derived above, and assuming a logarithmic form for $v$, we obtain the following expression:

$$
\begin{array}{r}
c^{n}(K)+\log (\theta f(K)-B+\lambda)+\beta\left[c^{n}\left(k^{n}\right)+\log \left(\theta f\left(K^{n}\right)+\lambda\right)\right] /(1-\beta) \geq \\
c^{d}(K)+\log (\theta \alpha f(K)+\lambda)+\beta\left[c^{d}\left(k^{d}\right)+\log \left(\theta \alpha f\left(K^{d}\right)+\lambda\right)\right] /(1-\beta)
\end{array}
$$

Rearranging terms:

$$
\begin{array}{r}
\log (\theta f(K)-B+\lambda) \geq c^{d}(K)-c^{n}(K)+\log \left(\theta \alpha f\left(K^{d}\right)+\lambda\right)+ \\
+\frac{\beta}{1-\beta}\left\{\left[c^{d}\left(k^{d}\right)+\log \left(\theta \alpha f\left(K^{d}\right)+\lambda\right)\right]-\left[c^{n}\left(k^{n}\right)+\log \left(\theta f\left(K^{n}\right)+\lambda\right)\right]\right\}
\end{array}
$$


Defining $A$ as

$$
A=c^{d}(K)-c^{n}(K)+\frac{\beta}{1-\beta}\left\{\left[c^{d}\left(k^{d}\right)+\log \left(\theta \alpha f\left(K^{d}\right)+\lambda\right)\right]-\left[c^{n}\left(k^{n}\right)+\log \left(\theta f\left(K^{n}\right)+\lambda\right)\right]\right\}
$$

We write 3.9 as

$$
\log \left[\frac{(\theta f(K)-B+\lambda)}{\left(\theta \alpha f\left(K^{d}\right)+\lambda\right)}\right] \geq A
$$

From which we obtain the expression for $\bar{b}_{w}(K)$ as the level of $B$ that makes 3.10 holds with equality.

$$
\bar{b}_{w}(K)=\underbrace{\theta f\left(k_{t}\right)-\left(\exp (A) \theta \alpha f\left(k_{t}\right)\right)}_{\mathrm{C} \& \mathrm{~K} \text { expression }\left(\bar{b}_{b}(K)\right)}+\lambda(1-\exp (A))
$$

where $\exp (A)<1$, that is, $\bar{b}_{w}(K)>\bar{b}_{b}(K)$.

Analytically, the inclusion of a foreign transfer increases $\bar{b}(K)$.

As we mentioned above, we will test different specifications for the oil windfall: First, we will treat $\lambda$ as a pure exogenous transfer, in this case $\lambda$ will be a number that reproduces the oil windfall. Second, we endogenize $\lambda$ as a function of the state of the economy, specifically we asume $\lambda$ is a fraction of non-oil GDP.

Following we will determine the quantitative impact of this transfer in the economy described above parameterized for the Venezuela case.

\section{Results}

This section presents a numerical example whose parameters have been chosen so it reproduces certain features of the Venezuelan economy in 2003, the year of study. The objective of this exercise is to determine the size of the crisis zone, analyze if the Venezuelan debt stock is inside this zone, the combination of policies the government can pursue in order to abandon such a zone and the feasibility of these policies.

First, we describe the parametrization made for the Venezuelan case. Second, we show the results obtained by the model described in the previous section for an economy without oil which we call $\mathrm{C} \& \mathrm{~K}$ baseline, and whit an economy whit oil for each of the two specifications for the windfall described above. Third, we carry out policy experiments.

We adopt the same utility function as Cole and Kehoe (1996) 


$$
E \sum_{t=0}^{\infty} 0.99^{t}\left(c_{t}+\log \left(g_{t}\right)\right)
$$

Technology and resource restriction are given by

$$
\begin{aligned}
& f(K)=2 K^{0.55} \\
& c+g+k^{\prime}-0.996 k+z B \leq 2 k^{0.55}+q B^{\prime}+\lambda^{\prime}
\end{aligned}
$$

Given a default probability $\pi$, and assigning values to the parameters we determine $k^{\pi}$ through 3.6

$$
(1-\theta)\left[((1-0.04)+0.04 \alpha) 1.1\left(k^{\pi}\right)^{-0.45}-0.004\right]=1 / 0.99
$$

We interpret the period of our economy $t$ as being $5 / 12$ of a year, given that during 2003 the average weighted ${ }^{16}$ maturity of the Treasury bills ${ }^{17}$ was 141 days $^{18}$. The value of $\beta$ of 0.99 , corresponds to a yearly discount factor of 0.99 which implies a yield of $1.01 \%$ on risk-free bonds (average yield on U.S 90 days T-bills during 2003). We fix the probability of default $\pi$ at 0.04 , in order to obtain a yield of $12.5 \%\left(=[\beta(1-\pi)]^{-12 / 5}-1\right)$ on local bonds, which are the dollar equivalent to a local currency (bolivars) yield of $24.6 \%$ for Treasury bills with a maturity between 81 and 110 days during 2003 .

The capital share of GDP is obtained from a calibration made by Saez and Puch (2003) and set at 0.55 . A depreciation rate of $\delta=0.004$ corresponds to a yearly depreciation rate of $0.01\left(=1-\beta^{5 / 12}\right)$.

We fix $\theta$ at 0.1563 , so it reproduces a ratio of government non-oil revenues over nonoil GDP of $14 \%$. Investment/GDP ratio in the model is $10.42 \%$, lower than the $11.7 \%$ reported in Venezuela's official figures.

The oil windfall $\lambda$ is set according the specification we use. For the exogenous case we fix $\lambda$ to match a government oil revenue over GDP ratio of $11.26 \%$. In the endogenous specification we assume $\lambda$ is a fraction of $f\left(k_{t}\right)$, where such fraction is equal to the government oil revenue over non-oil GDP ratio of $13.74 \%$.

\footnotetext{
${ }^{16}$ The weights are equal to the size of the issues.

${ }^{17}$ We take this instrument as the representative bond due to a greater liquidity and because their yield is used to determine the coupon value of the VEBONOS.

${ }^{18}$ We carried out experiments using other specifications for $t$. Besides $5 / 12$, we made the experiment with $141 / 365$ and $141 / 250$, even though the quantitative results slightly change the qualitative results and conclusions remain the same.
} 
Finally we set $\alpha=0.95$ as Cole and Kehoe (1996) and Da-Rocha, Giménez, and Lores (2004) did for the Mexican and Argentinean case respectively, which implies a permanent drop in productivity of $5 \%$ if it were to default.

\section{Results}

In table 2 we show the crisis zone for each of the three economies considered. In the first line we show $\mathrm{C} \& \mathrm{~K}$ baseline model (without oil), we observe a very low limit for the crisis zone compared to Venezuela's internal debt/GDP ratio of $16.9 \%$, in this case the Venezuelan economy is clearly exposed to a rollover risk. In the second line we show the crisis zone for the case where we include the oil windfall in an exogenous manner, we can observe a sharp increase in both limits (178\%), but not sufficient as to exit Venezuela from a crisis zone. Nevertheless, given the presence of the exogenous windfall $(\lambda)$, the combination of policies needed to abandon the zone are by far more feasible to implement than those implied by $\mathrm{C} \& \mathrm{~K}$ baseline model.

Table 2: Crisis Zone

\begin{tabular}{c|cc}
\hline \hline & $\bar{b}\left(K^{\pi}\right)$ & $\bar{B}\left(K^{\pi}\right)$ \\
\hline C\&K baseline & $4.9 \%$ & $102 \%$ \\
Windfall exogenous & $13.6 \%$ & $283.6 \%$ \\
Windfall endogenous & $18.6 \%$ & $388.8 \%$ \\
Internal Debt /GDP & \multicolumn{2}{|c}{$16.9 \%$} \\
\hline \hline
\end{tabular}

We can observe in table 3 a comparison between the increments needed in the tax rate and debt maturity to exit the crisis zone, in the baseline and augmented model.

In the baseline model an average maturity of 17 months completely eliminates the rollover risk ${ }^{19}$, while in the augmented model only an average maturity of 5.6428 months is needed to abandon the crisis zone.

In figure 3 we observe that for every maturity, the lower limit is greater in the augmented model.

Increasing the tax rate separately ceteris paribus, in order to eliminate the rollover risk the tax rate should be 0.5 in the baseline model (government revenue over GDP ratio of $46.21 \%$ ) and 0.1685 in the augmented model (government non-oil revenue over GDP ratio of $15.11 \%$ ).

\footnotetext{
${ }^{19}$ Assuming the tax rate and the size of the windfall are constant.
} 
Table 3: Sensibility Analysis

\begin{tabular}{|c|c|c|}
\hline & $\Delta \% \theta \quad \Delta \% t$ & $\begin{array}{c}\Delta \lambda \\
(\% \mathrm{GDP})\end{array}$ \\
\hline \multirow{2}{*}{ C\&K baseline } & \multicolumn{2}{|c|}{$246 \%$} \\
\hline & \multicolumn{2}{|c|}{ Maturity $=5$} \\
\hline \multirow[t]{2}{*}{ Windfall exogenous } & $13 \%$ & 0.01 \\
\hline & \multicolumn{2}{|c|}{ Maturity $=5.5$} \\
\hline Windfall exogenous & $11 \%$ & 0.002 \\
\hline
\end{tabular}

In terms of GDP percentage points, the increase in tax pressure should be of 32 points in the base model, against an increase of 7.5 points in the augmented model. This huge difference is explained by the presence of the windfall. In the base model the tax rate represents total government revenues while in our version the windfall represents $49.6 \%$ of such revenues, which implies a greater tax increment in the base case to generate a greater effective tax rate.

The presence of a government revenue that does not depend on policies that tax the private economy, gives a greater ability to make adjustments. In both versions of the model tax increments have adverse effect on capital accumulation and therefore the future tax base. In both models as the tax rate $\theta$ rises the increment in the upper limit of the crisis zone is greater than the increment in the lower limit (see figure 4 for the baseline case), which implies that the crisis zone widens due to an expansion of the tax pressure. Therefore, lower increases in tax rate implies lower tax base reductions.

Although the windfall $(\lambda)$ is an exogenous variable out of control of fiscal authorities, we analyze the increase in terms of GDP points needed to leave the crisis zone. We observe (see table 3 ) that an expansion of oil revenue in 0.01 points eliminates rollover risk, that is, a further increase in oil prices makes government debt policy easier to sustain.

Also, we can observe in table 3 that if we increase debt maturity in just half-month the effort in terms of increments in tax and maturity reduces substantially, around $17 \%$ in average.

An alternative way to eliminate the rollover risk would be to reduce the stock of internal debt until it exits the crisis zone. It is optimal to run debt down to $\bar{b}\left(k^{\pi}\right)$ in one period, the difference is that in the augmented model such adjustment represents 


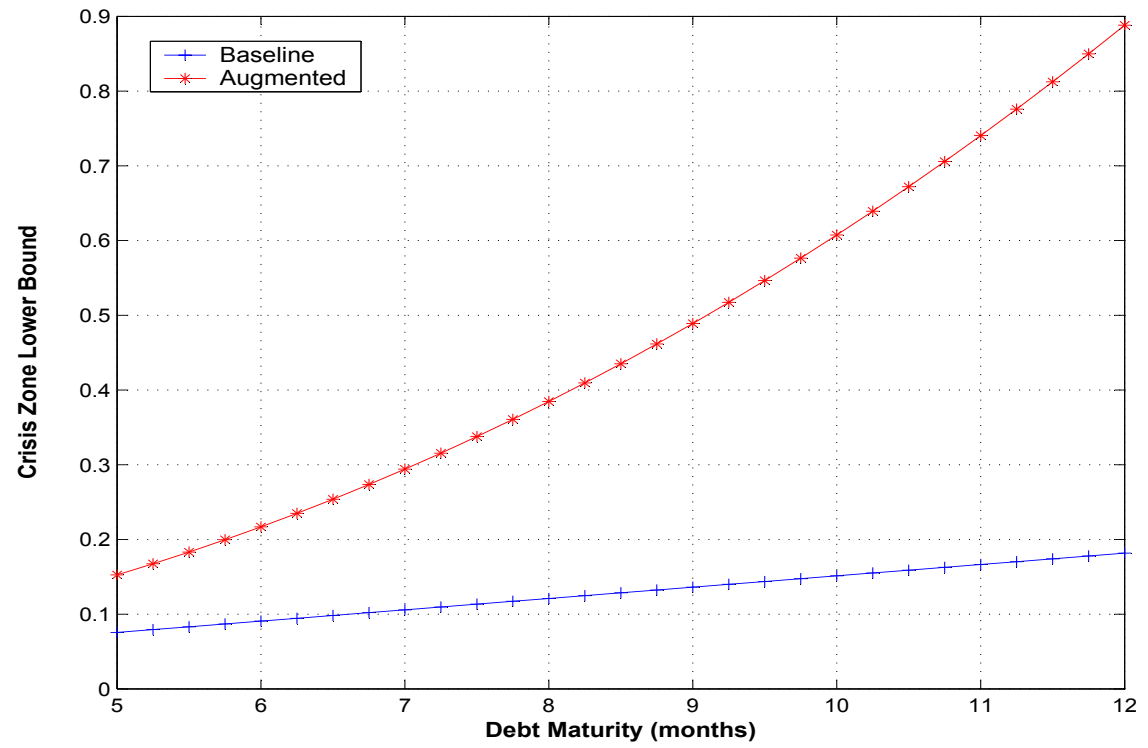

Figure 3: Crisis Zone Lower Bound

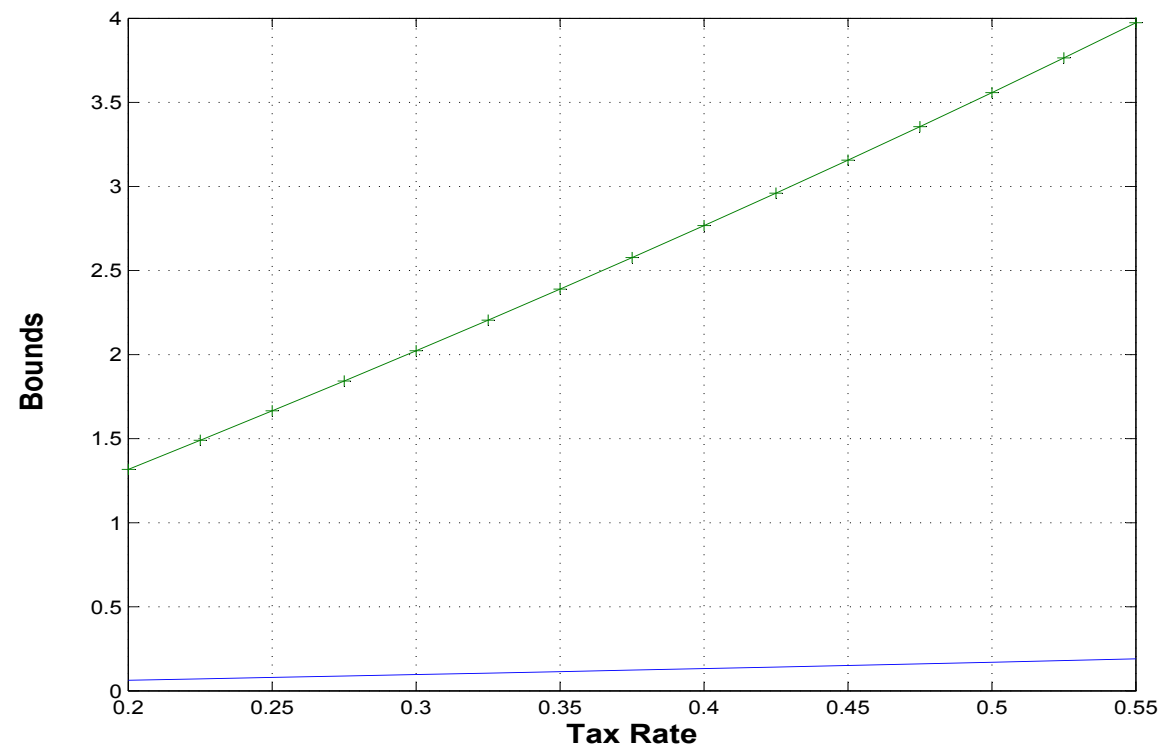

Figure 4: Tax Rate and Crisis zone 
an internal debt/GDP reduction of 1.68 points against a 9.34 points reduction in the baseline model.

In the third line of table 3 we observe the crisis zone for the case where we include the oil windfall in an endogenous manner. We observe that in this case the venezuelan economy exit from the crisis zone, that is, this economy would not be exposed to a debt crisis due to bankers adverse expectations.

Notwithstanding, the lower limit are just slightly above the internal debt GDP ratio.

This feature opens the following question: what happens if oil prices suddenly falls?. Maybe the economy would enter the crisis zone, and therefore be exposed to a stochastic debt crisis.

\section{Conclusions}

We build a model of a small open economy that receives an external transfer, to study if the presence of a windfall can counteract a expectations driven debt crisis due to short debt maturity. We find that crisis can be eliminated for a given size of the windfall, depending on the model's parameter values.

The model is applied to the Venezuelan economy, to analyze if the current oil windfall can make Venezuela exit from a crisis zone. Using 2003 data we test different specifications for the windfall and determine that given an internal debt over GDP of $16.9 \%$ and a government oil revenue over GDP of $11.26 \%$ (oil windfall proxy), crisis can be eliminated for a given specification of the windfall, depending on the model's parameter values.

For those cases where the economy don't abandon the crisis zone, we find a notable increase in the lower limit of the crisis zone (178\% in our numerical experiment), and that the combination of policies needed to abandon the zone are by far more feasible to implement in practice that those implied by the baseline model without a windfall. For example, debt maturity must increase in just two weeks to eliminate the exposure to the rollover risk due to short debt maturity. This is a completely feasible policy compared to a 12 months increase in the baseline version.

This result helps us to understand why, although Venezuela fiscal authority implemented a debt policy that results in a shortening of debt maturities, and therefore an increasing exposure to rollover risk, most analysts and market participants don't expect any payment disruption in the short term. 
The presence of the oil windfall notably increase creditworthiness, and gives the government a greater ability to make adjustments in terms of increases in maturity and tax pressure, as our experiments shows.

\section{References}

Borenztein, E., M. Chamon, O. Jeanne, P. Mauro, and J. Zettelmeyer (2004): "Sovereign Debt Structure for Crisis Prevention," Occasional Paper 237, International Monetary Fund, Washington.

Cole, H. L., And T. J. Kenoe (1996): “A Self-Fulfilling Model of Mexico's 1994-95 Debt Crisis," Journal of International Economics, 41, 309 - 330.

(2000): "Self-Fulfilling Debt Crises," Review of Economic Studies, 67(1), 91116.

Da-Rocha, J.-M., E. L. Giménez, And F.-X. Lores (2004): "Devaluation Beliefs and Debt Crisis: The Argentinian Case," Research Group in Economic Analysis Working Paper Series 8-04. Universidad de Vigo.

Farmer, R. E. A. (1993): The Macroeconomics of Self-Fulfilling Prophecies. The MIT Press, first edn.

IMF (2003): "World Economic Outlook," International Monetary Fund. Washington DC.

OAEF (2003): "Informe sobre el Manejo de la Deuda Pública y del Proceso de Reordenamiento de la Deuda Pública Interna Efectuada en el 2002," Informes de Análisis y Contenido IA 0603-059, Oficina de Asesoría Económica y Financiera de la Asamblea Nacional, Venezuela.

Saez, F., And L. Puch (2003): "Trade Shocks and Aggregate Fluctuations in an OilExporting Economy," Documentos de Trabajo ICAE 0301, Universidad Complutense de Madrid.

WB (2003): “Global Development Finance 2003," World Bank. Washington DC. (2005): “Global Development Finance 2005," World Bank. Washington DC. 